DOI $10.31168 / 2618-8597.2021 .16 .25$

\title{
IMPERIAL PATTERNS IN THE CIRCULATION OF GRAMMATICAL KNOWLEDGE IN THE BALKANS ${ }^{1}$
}

\author{
Vladislava Warditz \\ Lehrstuhl für Slavische Sprachwissenschaft, \\ Universität Potsdam (Potsdam, Deutschland) \\ vladislava.warditz@uni-potsdam.de
}

\section{TRANSLATION, TRANSFER AND CIRCULATION OF KNOWLEDGE}

Within the paradigm of History of Knowledge (cf. Burke 2012, 2016, 2017), much attention has been given to the transfer of knowledge, notably through translation. In the field of Slavic Studies, this has resulted in research into the diverse socio-cultural, ideological and linguistic patterns of the reception and distribution of knowledge in the age of Enlightenment (Lehmann-Carli et al. 2001, 2008; Keipert 2013; Coudenys 2016; Coudenys \& Warditz 2021).

However, transfer, like translation, implies directionality, suggesting an imbalance of power between sending and receiving cultures. Therefore, it is safer to see translation as a position on a gliding scale of modes within the broader and multidirectional concept of circulation of knowledge (Feichtinger et al. 2020; Östling et al. 2019; Mackenthun et al. 2017; Keim 2014; Darbellay 2012).

On the basis of this research concept, the present study examines circulation and distribution of grammatical knowledge (among others, via translation) in the Balkans in the age of Enlightenment, with a special focus on patterns of German origin therein. This is an episode in a longer history of circulation of knowledge, notably in the field of the grammar-writing in the Balkans.

\section{ACADEMIC SPACES AND SCIENTIFIC PATTERNS}

During the period under scrutiny, the academic interest in the Slavic and Balkan realm was not yet defined within the framework of nation-states, but by an imperial context. Slavic and Balkan ethnic and language communi-

The article was written within the framework of the research project "Migration, Wissenstransfer und Slawistik: Der Fall Max Vasmer", funded by the Gerda-Henkel-Stiftung. 
ties were living under Russian, Habsburg or Osman rule, and distinct national academic traditions did not yet exist. Therefore it is difficult, if not impossible to define and distinguish different national academic traditions within these imperial geopolitical and educational settings; to examine them separately, without taking into consideration the diffusiveness of borders, would amount to an anachronism (Burke 2016: 28). Ukrainian, Belarussian and Ruthenian, for instance, at the later age of Enlightenment in Russia, had no status of an independent language, cf. Pallas' Vocabularia comparative (1786/1787 - 1789).

The Russian imperial, monocentric view of other Slavic languages remained dominant in Russian academic space until the 20th century; scholars like Jan Baudouin de Courtenay or Max Vasmer were among the first to question this view and started to focus on non-written minority languages and language contact, among others in the Balkans. These researchers, however, were trained in the imperial academic tradition, and this tradition also determined the paradigms and methodologies they applied to their novel field of research, including lexicography, grammar-writing or even language documentation. As such, an imperial, homogeneous identity was the necessary backdrop against which language diversity could be established and studied.

Imperial academic spaces, however, were not only defined by (mono)centrism. From the very beginning, Slavic studies within the academic tradition of the Russian and even more of the Habsburg Empires were shaped by multilingual representants from "non-titular" ethnic communities, such as the aforementioned Polish linguist Baudouin de Courtenay in Russia. The Slovenian Franc Miklošič and his successor, the Croat Vatroslav Jagić occupied similar positions at the University of Vienna: they steered Slavic studies away from being a marginal topic within Historic-Comparative Linguistics, and gave it the status of a distinctive philology, with its own targets and methodology. Moreover, these scholars crucially contributed to the development of the description of Slavic languages and cultures. In doing so, they incarnated Peter Burke's idea that "Displaced ideas often come from displaced people" (2016: 21). Thus, language and ethnic diversity within the Empire had been partial to the creation of a politically adequate academic discourse. As such, it may serve as an example of regulation of circulation of knowledge in line with imperial ethnic and language policies. On the other hand, however, imperial policies also made the center 'blind' for knowledge in 'peripheral' Slavic communities (cf. Burke 2016, 32); the 'ignorance' of the center 
proved to be a valuable resource for the establishment of studies of language diversity within the imperial context. The sketched interaction can be seen as a fertile antagonism between central and peripheral imperial tendencies in academia.

As the Russian and Habsburg (Austro-Hungarian as of 1867) academic spaces interconnected and intersected (at least until the demise of both Empires), there are large similarities in their organization and functioning. This included the search for common linguistic and cultural patterns, which can be seen as the geopolitically determined establishment of centripetal tendencies in reply to centrifugal ones. Therefore, in imperial academic spaces, the role of unifying patterns as provided by educational policies and the educational system, were reflected in scientific practices, such as grammar-writing. Accordingly, grammar-writing in the imperial context, e.g. in the Habsburg and/or Russian academic space can be seen as politicum.

\section{GRAMMAR-WRITING AS POLITICUM: PATTERNS OF IMPERIAL POWER}

The circulation and distribution of grammatical knowledge in both Empires in the Age of (late) Enlightenment, as well as the coexistence of both imperial (unifying) patterns in Slavic (and Balkan) grammar-writing can be illustrated by the following example. The Handbook of Slavonic Grammar (Руководство к славенстјеј граматиије, 1794, Ofen/Vienna) by the Serbian luminary Avram Mrazović was written as an abridged revision of Meletij Smotrickij's Grammar (Грамматіки славєнския правилноє Сvнтатма, Vievis, 1619); Smotrickij not only determined Slavic grammar-writing for a long time, but also had an impact on other, non-Slavic grammatical traditions, such as Ludolph's Grammatica Russica (Oxford, 1696).

However, with regard to the use of grammatical terminology, Mrazovic was indebted to Johann Ignaz von Felbiger's Handbook of the German Language Teaching (Die Anleitung zur deutschen Sprachlehre, 1775, Vienna, as of 1779 republished as Die verbesserte Anleitung zur deutschen Sprachlehre) (Keipert 1991). For his terminology and structure, Felbiger, who had been invited by Empress Maria Theresa to help reform the (German-based) school system in Habsburg Empire, was in turn indebted to Johann Gotsched's Grammar (Grundlegung einer deutschen Sprachkunst, Leipzig, 1748). Maria Theresa's school reforms aimed to create $a$ sense of national unity among the ethnically and linguistically diverse population of the Habsburg Empire; therefore, German patterns in the distribution of grammar knowledge in the 
imperial education space were deemed suitable. Moreover, as authoritative educational patterns, they or their translations further lay at the basis of grammar-writing of other languages of the Empire, e.g. Croatian (Marijan Lanosović, Anleitung zur slavonischen Sprachlehre, Ofen, 1797) and Hungarian (Georg Nagy, Einleitung in die ungarisch-philosophische Sprachlehre, Wien, 1793) (Nyomarkay 1999). Last but not least, Felbiger's Handbook served as a (translated) model for the handwritten Russian Grammar by Barsov (1783-1788) (Uspenskij 1981). As such, the pattern was adopted in another imperial academic space as well.

Summarizing, we can say that the observed circulation of grammar knowledge demonstrates complex interactions of different Slavic- and Germanbased models and patterns that effectively reflect distribution of power in the given geopolitical space.

\section{REFERENCES}

Burke 2012 - Burke P. The circulation of historical and political knowledge between Britain and the Netherlands, 1600-1800: The place of translations. // Cook H. J. / Dupré S. (eds.). Translating knowledge in the early modern Low Countries. Wien-Berlin: Lit Verlag, 2012. P. 41-50.

Burke 2016 - Burke P. What is the history of knowledge? Cambridge: Polity Press, 2016.

Burke 2017 - Burke P. Exiles and Expatriates in the History of Knowledge, 15002000. Massachusetts: Waltham, 2017.

Coudenys 2016-Coudenys $W$. Translation and the emergence of history as an academic discipline in 18th-century Russia // Kritika 17 (4). P. 721-752.

Coudenys, Warditz 2021 - Coudenys W., Warditz V. Is translation child's play? Circulation of knowledge in Lomonosov's Kratkij rossijskij letopisec (1760) and its Translations // Die Welt der Slaven 66 (2021), 46-69.

Darbellay 2012 - Darbellay $F$. The circulation of knowledge as an interdisciplinary process: Travelling concepts, analogies and metaphors // Issues in integrative studies 30 (01/01 2012). P. 1-18.

Feichtinger et al. $2020-$ Feichtinger J. et al. (eds.) How to write the global history of knowledge-making: Interaction, circulation and the transgression of cultural difference. Cham: Springer, 2020.

Keim $2014-$ Keim $W$. Conceptualizing circulation of knowledge in the social sciences // Keim W. et al. (eds.). Global knowledge in the social sciences. Made in circulation. Farnham: Ashgate, 2014. P. 87-113. 
Keipert 1991 - Keipert H. Die „Wiener Anleitung“ in der slavischen Grammatikographie des ausgehenden 18. Jahrhunderts // Zeitschrift für Slavische Philologie 51 (1), 1991. S. 23-59.

Keipert 2013 - Keipert H. Die Pallas-Redaktion der Petersburger Vocabularia comparativa und ihre Bedeutung für die Entwicklung der slavischen Sprachwissenschaft // Historiographia Linguistica 40 (1/2), 2013. S. 121-149.

Lehmann-Carli et al. 2001 - Lehmann-Carli G. et al. (eds.). Russische AufklärungsRezeption im Kontext offizieller Bildungskonzepte (1700-1825), Aufklärung und Europa. Berlin: Berliner Wissenschaftsverlag, 2001.

Lehmann-Carli et al. 2008 - Lehmann-Carli G. et al. (eds.). Göttinger und Moskauer Gelehrte und Publizisten im Spannungsfeld von Russischer Historie, Reformimpulsen der Aufklärung und Petersburger Kulturpolitik. Berlin: Frank und Timme, 2008.

Mackenthun et al. 2017 - Mackenthun G. et al. (eds.) 2017: Introduction // Mackenthun G. et al. (eds.). Travel, agency, and the circulation of knowledge. Münster, New York: Waxmann, 2017. P. 7-38.

Nyomarkay 1999 - Nyomarkay I. Der Einfluss der Wiener Grammatiken auf die Grammatikographie der Völker der Monarchie // Wiener Slavistisches Jahrbuch 45, 1999. S. 127-132.

Östling et al. 2019 - Östling J. et al. (eds.). Circulation of knowledge. Explorations in the history of knowledge. Lund: Nordic Academic Press, 2019.

Uspenskij 1981 - Uspenskij B.A. (Hg.). Rossijskaja grammatika Antona Alekseeviča Barsova. Moskva: Izd-vo MGU, 1981. 